\title{
Temporal variations in viral distributions in the anoxic Cariaco Basin
}

\author{
G. T. Taylor*, C. Hein, M. Iabichella \\ Marine Sciences Research Center, Stony Brook University, Stony Brook, New York 11794-5000, USA
}

\begin{abstract}
Virus-like particles (VLP), collected from the permanently anoxic Cariaco Basin between 10 October 1996 and 2 November 1999, were enumerated in water column and sediment trap samples. Vertical distributions of VLP from 18 depths between 7 and $1310 \mathrm{~m}$ generally corresponded to those of bacterial abundance and bacterial net production (BNP), with primary maxima consistently found in surface waters and midwater maxima near the $\mathrm{O}_{2} / \mathrm{H}_{2} \mathrm{~S}$ interface. Temporal variations in VLP concentrations $\left(0.81\right.$ to $\left.630 \times 10^{8} \mathrm{VLP} \mathrm{l}^{-1}\right)$ were highly correlated with chlorophyll a (chl a), bacterial abundance and BNP in the upper $250 \mathrm{~m}$. In the redox transition zone (RTZ $=250$ to $450 \mathrm{~m})$, VLP abundance covaried with bacterial growth rates, but not bacterial abundance nor chemoautotrophic production. In the anoxic layer ( $>450 \mathrm{~m}$ ), temporal variations in VLP abundance were not significantly correlated with any measured variable. In the RTZ, the median VLP:bacteria ratio (VBR $=3$ ) was significantly lower than in the oxic $(\mathrm{VBR}=16)$ and anoxic $(\mathrm{VBR}=31)$ layers for all observations, suggesting varying relationships between viruses, hosts and environment among these layers. Vertical fluxes of VLP associated with sedimenting debris varied between 0.39 and $520 \times 10^{9}$ VLP m${ }^{-2} \mathrm{~d}^{-1}$, a range similar to bacteria $\left(0.88\right.$ to $330 \times 10^{9}$ bacteria $\left.\mathrm{m}^{-2} \mathrm{~d}^{-1}\right)$. VBRs in the sinking inventories were very low, varying from 0.01 to 1.2 and averaging 0.60 , suggesting that VLP are not as numerically important in sinking particles as they are in suspended communities. Comparisons of sinking fluxes with suspended VLP inventories indicate that vertical transport is relatively unimportant in redistributing viruses in the water column. Estimated removal rates by sinking from the oxic, transition and anoxic layers averaged $0.11 \% \mathrm{mo}^{-1}(\mathrm{n}=16)$ for apparent VLP.
\end{abstract}

KEY WORDS: Viruses · Bacteria · Anoxia · Bacterial production · Microbial loop · Cariaco Basin Resale or republication not permitted without written consent of the publisher

\section{INTRODUCTION}

Over the last decade, results from field surveys and experimental studies suggest that viruses play a pivotal role in the microbial loop of natural waters (Bratbak et al. 1990, 1992, 1994, Proctor \& Fuhrman 1990, Fuhrman \& Suttle 1993, Murray \& Eldridge 1994, Wommack \& Colwell 2000). Until recently, phagotrophic protozoa were believed to be the primary agents of mortality for bacteria and small algal species. However, experimental and modeling studies indicate that microplankton mortality resulting from viral lysis may

*Email: gtaylor@notes.cc.sunysb.edu rival protozoan grazing under some conditions (Fuhrman \& Noble 1995). Viral lysis has been estimated to account for between 6 and $62 \%$ of bacterial mortality alone in aquatic systems and is highly variable (Suttle \& Chen 1992, Proctor et al. 1993, Thingstad 2000). For example, in the oxic layer of Lake Plußsee, 82 to $100 \%$ of bacterial mortality could be explained by bacterivorous flagellates, while viral lysis appeared to be increasingly important in the metalimnion and anoxic hypolimnion (Weinbauer \& Höfle 1998a). In terms of pelagic carbon cycling, viruses mediate a pathway for return of labile organic matter to dissolved and particulate pools by lysing host cells (Bratbak et al. 1992). From a trophodynamic perspective, viral infections divert some microbial production away from higher trophic 
levels, thereby increasing supply of respiratory carbon to the lowest trophic levels (bacteria and protozoa) and diminishing overall system efficiency by introducing additional trophic iterations for biologically essential elements (Murray \& Eldridge 1994).

Using electron microscopic and epifluorescent microscopic techniques, free virioplankton and viralinfected microplankton have been shown to be plentiful in a variety of lacustrine, estuarine, coastal, oceanic and hypersaline environments from the tropics to the poles (e.g. Proctor \& Fuhrman 1990, Bird et al. 1993, Cochlan et al. 1993, Oren et al. 1997, Weinbauer \& Höfle 1998a, Steward et al. 2000). With few exceptions, surveys have been confined to oxic surface waters with 1 oceanic profile extending down to $5000 \mathrm{~m}$ (Hara et al. 1996). In oceanic profiles, virioplankton concentrations correlate with distributions of the most abundant hosts (bacteria and phytoplankton) and their productivity, generally decreasing dramatically through the photic zone, and attaining low and constant concentrations at depth (Wommack \& Colwell 2000).

To the best of our knowledge, only 3 studies have examined viruses in anoxic environments: Maranger \& Bird (1996) in the Lac Gilbert hypolimnion and sediments; Drake et al. (1998) in Chesapeake Bay sediments; and Weinbauer \& Höfle (1998a) in the stratified water column of the eutrophic Lake Plußsee. Whether quantitative relationships between viruses and hosts are fundamentally different in anoxic and oxic systems is not known. In general, growth rates of anaerobic bacteria are considerably slower than those of aerobes, because usually only a small portion of an ecosystem's productivity is available to anaerobic food webs. Once delivered, matter and energy may be processed rapidly in anoxic systems, but less energy is converted to bacterial biomass, because anaerobic metabolism is inherently less efficient than aerobic; typical growth efficiencies being $\leq 10$ and $\leq 40 \%$, respectively (Fenchel \& Finlay 1994). These thermodynamic limitations, as well as sulfidic conditions selecting against many metazoans, can reduce trophic complexity in anoxic systems to as few as 2 or 3 trophic levels (Fenchel \& Finlay 1994). In principle, the low biosynthetic rates of anaerobic hosts should limit viral replication and transmission, and lead to lower virioplankton production in anoxic environments.

The present study examines variability in the abundance of virus-like particles (VLP) in the stratified Cariaco Basin, the world's largest, truly marine, permanently anoxic basin. The Cariaco Basin can be divided into 3 layers - oxic, redox transition and anoxic, analogous to the epilimnion, metalimnion and hypolimnion of a stratified anoxic lake. The oxic layer $(\sim 0$ to $250 \mathrm{~m}$ ) possesses the most complex trophic structure in which carbon metabolism is dominated by photosyn- thesis, aerobic heterotrophy, phagotrophy and nitrification. The redox transition zone (RTZ $=250$ to $450 \mathrm{~m}$ ) is biogeochemically stratified, appears less phylogenetically and trophically complex, and the processes of chemoautotrophy, fermentation, denitrification and anaerobic respiration prevail (Taylor et al. 2001). The anoxic zone ( 450 to $1400 \mathrm{~m}$ ) presumably has the simplest trophic structure and appears to support fermentation, sulfate reduction, methanogenesis and anaerobic methane oxidation (Madrid et al. 2001). Maxima in microbial standing stocks and activity are consistently observed in the photic zone (usually 0 to $60 \mathrm{~m}$ ). In addition, one or more midwater maxima are found in the RTZ underlain by diminishing stocks and activity below $450 \mathrm{~m}$. We hypothesize that distributions of viruses reflect distributions and activities of these stratified microplanktonic communities.

Surface waters of the Cariaco Basin are subject to strong seasonal upwelling, driving as much as 13-fold excursions in net primary production (NPP) between upwelling and non-upwelling seasons (Muller-Karger et al. 2001). The present study examines: (1) whether vertical and temporal patterns in VLP correspond to microplankton distributions and productivity; (2) whether relationships between viruses and hosts vary among the 3 redox layers; and (3) whether VLP distributions are influenced by their vertical transport in association with sinking biogenic debris.

\section{MATERIALS AND METHODS}

Site description and sampling. The Cariaco time series station is located in the eastern sub-basin of the Cariaco system (Fig. 1) in nearly $1400 \mathrm{~m}$ of water $\left(10.50^{\circ} \mathrm{N}, 64.66^{\circ} \mathrm{W}\right)$. Results from 8 cruises staged between 10 October 1996 and 7 May 1999 are presented from this single site. Sampling was conducted aboard the BO 'Hermano Ginés', operated by Estación de Investigaciones Marinas (EDIMAR), Fundación La Salle de Ciencias Naturales located on Isla de Margarita, Venezuela. Water samples were collected at 18 depths with a SeaBird rosette accommodating 12 Teflon-lined, 81 Niskin bottles. For hydrographic profiling, the rosette included a SeaBird CTD, a YSI oxygen probe, a Chelsea Instruments fluorometer for chlorophyll a $(\mathrm{chl}$ a) estimates and a Sea Tec c-beam transmissometer $(660 \mathrm{~nm})$. To resolve relatively narrow features, vertical sampling intervals for discrete samples were 10 to $20 \mathrm{~m}$ across the $\mathrm{O}_{2} / \mathrm{H}_{2} \mathrm{~S}$ interface and greater in shallow and deep waters (see Taylor et al. 2001). During each cruise, the $\mathrm{O}_{2} / \mathrm{H}_{2} \mathrm{~S}$ interface and particle layers were located using dissolved $\mathrm{O}_{2}$ and the transmissometer's beam attenuation data from CTD hydrocasts. 
Fig. 1. The Cariaco Basin in the Caribbean Sea and location of the time series Stn Cariaco $\left(10.50^{\circ} \mathrm{N}\right.$, $\left.64.66^{\circ} \mathrm{W}\right)$. The Cariaco system consists of 2 subbasins (east and west) connected by a saddle at a depth of $\sim 900 \mathrm{~m}$. Bathymetric contours are presented in $\mathrm{m}$

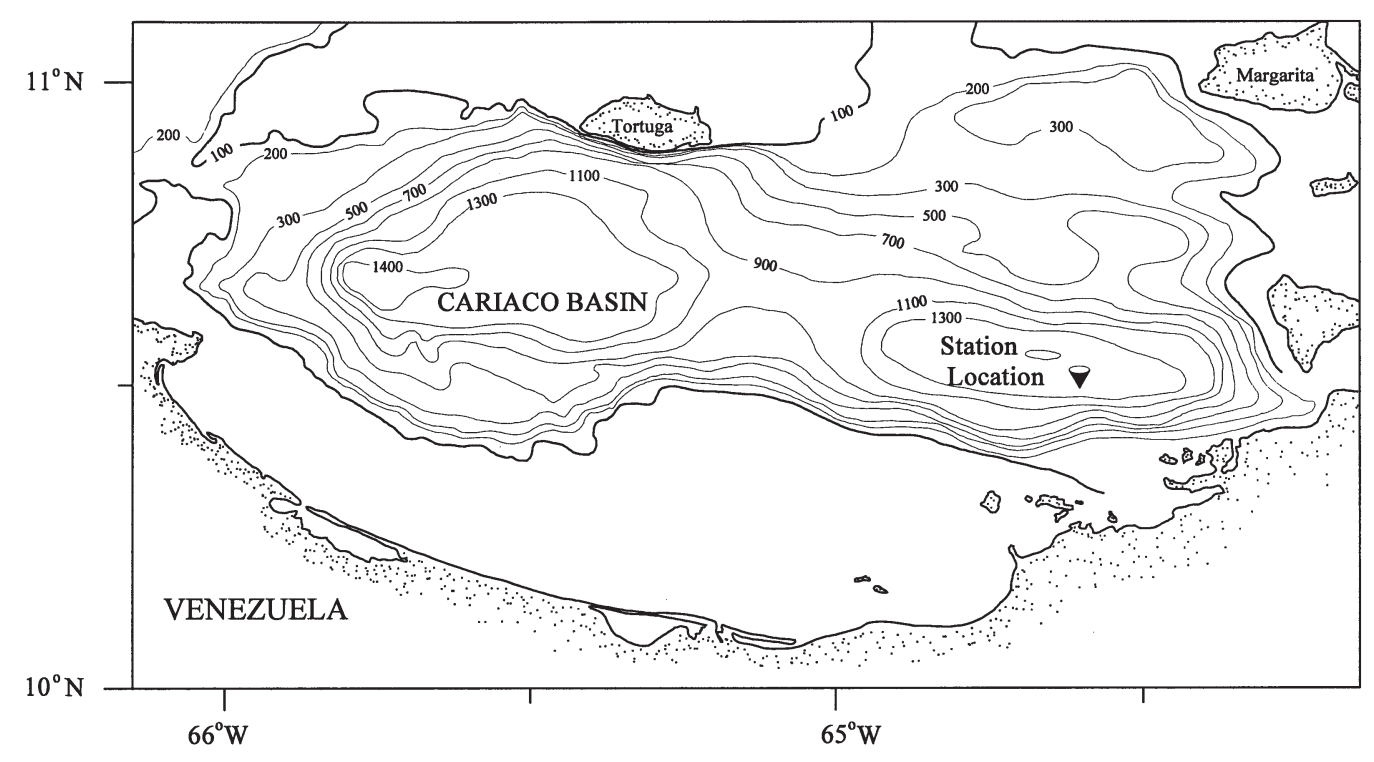

Abundance and biomass of suspended microbes. At each depth, whole water samples $(200 \mathrm{ml})$ were preserved with $2 \%$ (final conc.) borate-buffered formaldehyde and stored at 4 to $8^{\circ} \mathrm{C}$ until analyzed. In the laboratory, standard DAPI-stained slides were prepared on black $0.2 \mu \mathrm{m}$ Poretics polycarbonate membranes for enumeration of bacteria by epifluorescence microscopy using a Zeiss Axioskop at $1000 \times$ magnification (Porter \& Feig 1980). To determine biovolumes of bacteria, average cell dimensions were determined from 200 randomly selected cells in each sample using an ocular micrometer. For specific growth rate calculations, cellular carbon biomasses $(C)$ were estimated from biovolumes $(V)$ using an allometric carbon to volume extrapolation function $\left(C=0.12 V^{0.72}\right.$; Norland 1993). Average carbon content estimates for oxic layer communities varied from 44 to $49 \mathrm{fgC} \mathrm{cell}^{-1}$ (grand mean $=46 \pm 1.8$ ) between cruises and were in excellent agreement with Fukuda et al's. (1998) direct chemical determinations for a bacterial community in Tokyo Bay (48 $\mathrm{fg} \mathrm{C}_{\mathrm{C}} \mathrm{cell}^{-1}$ ). While not a direct validation of the microscopic approach's accuracy, agreement between these 2 independent methods for similar communities suggest our estimates are reasonable.

VLP in the same preserved samples were enumerated by epifluorescence microscopy at $1000 \times$ magnification according to Noble \& Fuhrman (1998). VLP from 0.3 to $2 \mathrm{ml}$ subsamples retained on $0.02 \mu \mathrm{m} \mathrm{Al}_{2} \mathrm{O}_{3}$ Anodisk $25 \mathrm{~mm}$ membranes (Whatman) were stained for 15 min under darkness with SYBR Green I fluorochrome (Molecular Probes). Preparations were airdried on absorbent paper to remove excess stain, then mounted on microscope slides by placing $30 \mu \mathrm{l}$ of antifade mounting solution between filter and cover slip. Mounting solution consisted of $1 \mathrm{ml}$ of 50/50 glyc-
erin/PBS (120 mM NaCl, $10 \mathrm{mM} \mathrm{NaH}_{2} \mathrm{PO}_{4}, \mathrm{pH}$ 7.5) and $10 \mu \mathrm{l}$ of a $10 \%$ aqueous solution of $p$-phenylenediamine. With the exception of the SYBR Green I primary stock, all solutions (diluents, buffers and mounting solution) were filtered through $0.02 \mu \mathrm{m}$ Anodisks prior to use to minimize inclusion of contaminant VLP in surveys. All results were corrected for reagent blanks whose VLP counts never surpassed $12 \%$ of the VLP observed in samples. SYBR Green I working stock and antifade mounting solution were made fresh daily. Biomass of VLP was estimated assuming an average carbon content of $0.2 \mathrm{fg} \mathrm{VLP}^{-1}$ (C. Suttle pers. comm.). We note that the median precision for VLP estimates (relative standard deviation, $\mathrm{RSD}=\mathrm{SD} /$ mean) is 0.30 and the range is between 0.03 and 0.91 ( $\geq 10$ fields analyzed for each of 139 samples). The major source of error is within-sample heterogeneity in VLP distributions across the Anodisk membranes. As reported in Kirchman et al. (1982) for bacterial enumeration, using replicate membranes only improved precision marginally while doubling analysis time. Therefore, reported results are obtained from single membranes. The median RSD for bacterial concentration and its range were smaller, 0.20 and 0.02 to 0.71 , respectively. Consequently, VLP and bacterial concentrations are only significantly different among samples if separated by factors greater than 1.3 and 1.2, respectively.

Sinking fluxes of particle-associated microbes. A sediment trap mooring was maintained by R. C. Thunell (University of South Carolina) at the site and consisted of 4 automated traps positioned at depths of approximately 275, 455, 930 and $1255 \mathrm{~m}$ (Thunell et al. 2000). Traps had a $0.5 \mathrm{~m}^{2}$ opening at the top and $13 \mathrm{col}-$ lection cups (550 ml capacity) at the bottom, each programmed to sequentially collect samples over $2 \mathrm{wk}$ 
intervals. Prior to deployment, collection cups were filled with buffered formalin $(2 \%)$ in filtered seawater to preserve accumulating organic matter and associated microbes. Upon retrieval, collection cups were sealed and refrigerated. Homogenized subsamples were obtained (courtesy of R. C. Thunell and E. Tappa) from all depths over 5 collection intervals for microbial enumeration; 13 to 20 November 1997, 26 February to 12 March 1998, 1 to 15 July 1998, 7 to 21 November 1998 and 21 October to 2 November 1999. In preparation for microscopy, subsamples were vigorously stirred magnetically, then aliquots were diluted 100fold in either filtered seawater with $2 \%$ formaldehyde (for bacteria) or $1 \mathrm{mM}$ saline tetrasodium pyrophosphate (35 $\mathrm{g} \mathrm{l}^{-1} \mathrm{NaCl}$ ) buffer (for VLP). No systematic difference in dispersion of bacteria was observed between diluents: seawater or pyrophosphate buffers varying in strengths from 0.5 to $9 \mathrm{mM}$. Diluted samples were sonicated for $20 \mathrm{~min}$ in a Bransonic Model 5200 ultrasonic bath to disaggregate debris and disperse microbes. Within the filtration funnel, aliquots (typically $0.3 \mathrm{ml}$ ) of these suspensions were further diluted approximately 10 -fold in particle-free seawater or pyrophosphate buffer to disperse particles across membranes. From this point, protocols for sample preparation for enumeration of bacteria and VLP were the same as described for water column samples. For all samples, a minimum of 300 individuals and 10 random fields were enumerated.

Heterotrophic bacterial production. Samples for bacterial net production (BNP) were transferred from Niskin bottles to $\mathrm{HCl}$-washed 11 Teflon-stoppered glass bottles under $\mathrm{N}_{2}$ atmosphere to prevent oxygenation of samples and sealed without headspace after overflowing $\sim 1$ to 2 vol. In the shipboard lab, samples were dispensed from these 11 bottles under $\mathrm{N}_{2}$ pressure through Tygon ${ }^{\circledR}$ tubing into HCI-washed, $40 \mathrm{ml}$ septa vials in triplicate and sealed (laminated Teflon-butyl rubber septa; Pierce) without headspace after overflowing. BNP was estimated from incorporation of $10 \mathrm{nM}^{3} \mathrm{H}$-leucine into protein according to Kirchman (1993) after 8 to $12 \mathrm{~h}$ incubations. ${ }^{3} \mathrm{H}$-leucine incorporation exhibited linearity for $>18 \mathrm{~h}$ in this system (not presented). A carbon production extrapolation factor of $3.1 \mathrm{~kg} \mathrm{C} \mathrm{mol}^{-1}$ leucine was employed (Kirchman 1993). Details of these measurements are presented in Taylor et al. (2001).

Autotrophic production. Photoautotrophic production in the upper $100 \mathrm{~m}$ of the water column was measured by standard ${ }^{14} \mathrm{C}$-bicarbonate protocols for primary production by the EDIMAR group (UNESCO 1994). Chemoautotrophic assimilation of inorganic carbon in subsurface waters was also measured by ${ }^{14} \mathrm{C}$-bicarbonate incorporation into particles. Details of both methods and results appear in Muller-Karger et al. (2001) and Taylor et al. (2001).
Statistics. Least-squares regressions, Pearson product-moment correlations and graphics were performed using SigmaStat 2.0 and SigmaPlot 2001 (SPSS). Kruskal-Wallis rank ANOVA and Kolmogorov-Smirnov normality tests were performed using SYSTAT (SPSS). For correlation tables, the group-wide Type I error rate, i.e. the probability that significant correlations arose by chance alone, was evaluated using the sequential Bonferroni test and a table-wide significance level, $\alpha$, of 0.05 (Rice 1989).

\section{RESULTS}

\section{Vertical distributions of VLP}

Typical vertical distributions of VLP from 2 of the 8 cruises sampled are presented in Fig. 2. VLP were usually most abundant in the upper $50 \mathrm{~m}$, attaining concentrations as high as $6.3 \times 10^{10} \mathrm{VLP} \mathrm{l}^{-1}$. VLP always exhibited at least 1 midwater peak between 200 and $400 \mathrm{~m}$, the zone where dissolved $\mathrm{O}_{2}$ drops below $20 \mu \mathrm{M}$ and disappears being replaced by $\mathrm{H}_{2} \mathrm{~S}$, resulting in the steepest gradient in chemical redox potential, the RTZ. Peaks in VLP abundance frequently, but not always, corresponded to peaks in bacterial abundance. While trends were coherent throughout most of the water column on 8 May 1997 (Fig. 2A), the largest midwater bacterial peak $(280 \mathrm{~m})$ was $20 \mathrm{~m}$ deeper than a comparable VLP peak (260 $\mathrm{m}$ ) and the small bacterial peak centered at $380 \mathrm{~m}$ was not reflected in VLP abundance. Likewise, on 14 November 1997 (Fig. 2B), small variations in bacterial abundance centered at 240 and $350 \mathrm{~m}$ were not completely reflected in VLP distributions.

Production of free VLP in the environment should vary in response to host production. In general, the depth distribution of BNP bears a strong resemblance to abundance of VLP and bacteria with peaks in the surface layer and midwater and low values between 100 and $200 \mathrm{~m}$ and below $400 \mathrm{~m}$ (Fig. 2). However, they vary in detail. For example, on 8 May 1997, BNP appears to vary in opposition to VLP and bacterial abundances at 150 and $220 \mathrm{~m}$, while corresponding to VLP peaks at 7, 15 and $260 \mathrm{~m}$ (Fig. 2A). On 14 November 1997, the bacterial peak at $240 \mathrm{~m}$ is not reflected in VLP or BNP distributions (Fig. 2B). Likewise on this date, the deep peak in BNP occurs at $330 \mathrm{~m}$, while the peaks in VLP and bacteria were located at $310 \mathrm{~m}$.

\section{VLP:bacteria ratios}

VLP:bacteria ratios (VBR) are useful to assess the numerical importance of VLP in systems presumed to be 


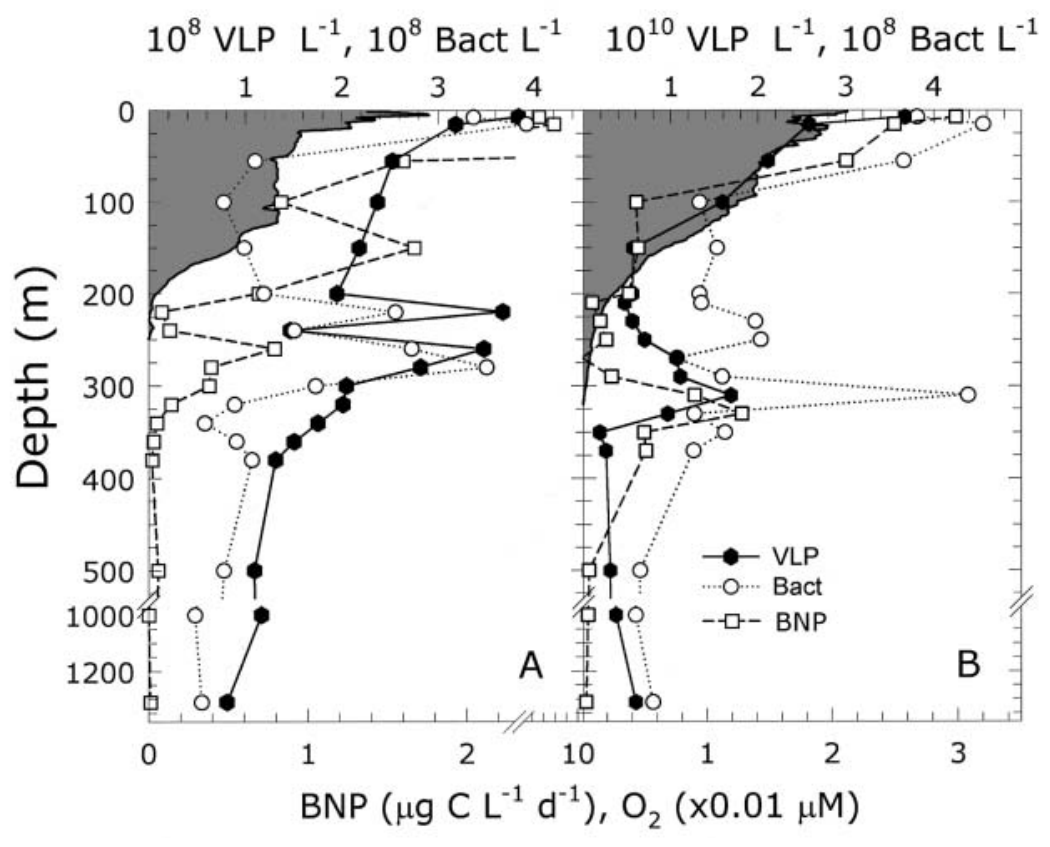

Fig. 2. Typical vertical profiles of concentrations of virus-like particles (VLP) and bacteria, and rates of bacterial net production (BNP) from Stn Cariaco on (A) 8 May 1997 (CAR-19) and (B) 14 November 1997 (CAR-25). The shaded areas in the upper $300 \mathrm{~m}$ define the oxic layer in both panels. Symbols represent means of each determination. Median precision of means (relative standard deviation, $\mathrm{RSD}=\mathrm{SD} /$ mean) were $0.30,0.20$ and 0.19 for VLP, bacteria and BNP, respectively. Note scale break in depth range and scaling factors for $x$-axes
Therefore, $\mu$ is conservative and may be subject to more vertical variability than is evident from these estimates.

\section{Temporal variability in VLP distributions}

Depths of midwater peaks in VLP abundance varied by as much as $80 \mathrm{~m}$ throughout our observations, corresponding to excursions of the $\mathrm{O}_{2} / \mathrm{H}_{2} \mathrm{~S}$ interface of similar magnitude. For example, midwater peaks in abundances of VLP, bacteria and BNP were shallower on 8 May 1997 than on 14 November 1997 in response to an $\mathrm{O}_{2} / \mathrm{H}_{2} \mathrm{~S}$ interface that was almost $70 \mathrm{~m}$ shallower, 250 versus $317 \mathrm{~m}$ (Fig. 2; $\mathrm{H}_{2} \mathrm{~S}$ not presented). Adjusting all available profiles to the depth of zero $\mathrm{O}_{2}$ (operationally $<3 \mu \mathrm{M}$ ) collapses some of the vertical variability in the midwater VLP peaks (Fig. 4A), similar to that observed in bacterial abundance (Fig. 4B). However, midwater bacterial peaks appear to be slightly dominated by viruses that parasitize bacteria (bacteriophages). VBR varied widely from 0.3 to 120 and averaged 22 for all observations of suspended communities. To assess whether VBR corresponded better to production normalized to bacterial community size than to BNP alone, specific growth constants, $\mu\left(\mathrm{d}^{-1}\right)$, were calculated from bacterial biomass estimates and measured BNP. Vertical trends in $\mu$ corresponded to those in VBR better than BNP over finite depth ranges on some dates, while not improving relationships on other dates (Fig. 3). For example, VBR and $\mu$ did not correspond very well on 8 May 1997 (Fig. 3A). However, on 14 November 97, with few exceptions, the depth trends of VBR and $\mu$ were similar in the upper $450 \mathrm{~m}$ (Fig. 3B), and unlike VLP and BNP (Fig. 2B), midwater peaks in VBR and $\mu$ corresponded reasonably well. An obvious limitation is that varying proportions of bacterial communities are actually growing and the calculation assumes that all cells are growing equally.

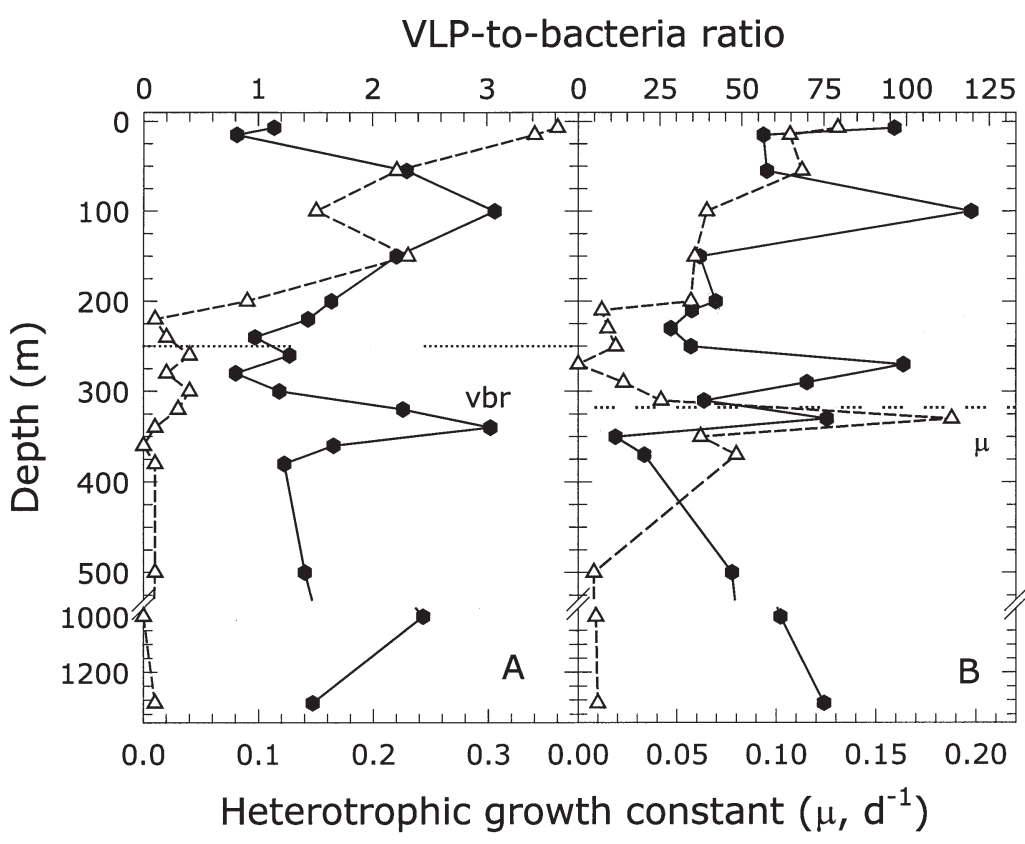

Fig. 3. Vertical profiles of virus-like particles (VLP):bacteria ratios (VBR) and heterotrophic bacterial growth constants ( $\mu=$ BNP/biomass) from Stn CARIACO on (A) 8 May 1997 (CAR-19) and (B) 14 November 1997 (CAR-25). Horizontal dotted line defines the $\mathrm{O}_{2} / \mathrm{H}_{2} \mathrm{~S}$ interface in both panels. Note scale break in depth range 
broader ( $\sim 50 \mathrm{~m}$ above and below the interface). Peaks in BNP appeared to be more narrowly constrained by the position of the $\mathrm{O}_{2} / \mathrm{H}_{2} \mathrm{~S}$ interface than bacterial abundances, generally residing between $10 \mathrm{~m}$ above and $30 \mathrm{~m}$ below the interface (Fig. 4C).

Temporal variability in VLP abundance is much greater than that of bacteria throughout the water column and slightly greater than that of BNP (Fig. 4). VLP integrated over the entire water column ( 0 to $1310 \mathrm{~m}$ ) varied by a factor of almost 100 over the observation period, from 1.9 $\times 10^{14}$ to $1.6 \times 10^{16}$ VLP m ${ }^{-2}$. Temporal excursions in integrated BNP were lower, varying by a factor of about 8, from 110 to $890 \mathrm{mgC} \mathrm{m}^{-2} \mathrm{~d}^{-1}$. Integrated bacterial standing stocks were far more constant, varying by less than a factor of 3 from 1.0 to $2.9 \times 10^{14}$ bacteria $\mathrm{m}^{-2}$.

\section{Comparison of oxic, transition and anoxic layers}

Considering the entire data set, VLP generally correlated with bacterial abundance $(\mathrm{r}=0.51, \mathrm{p}<0.001$,

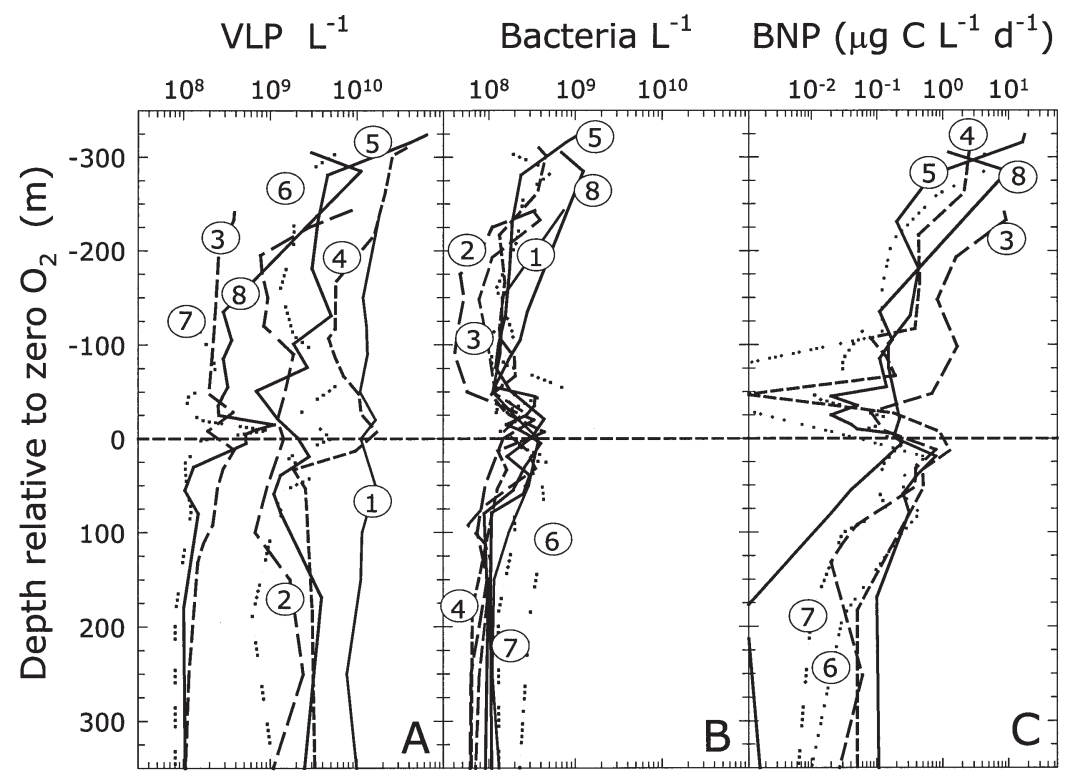

Fig. 4. Temporal variability in distributions of (A) virus-like particles (VLP), (B) bacteria and (C) bacterial net production (BNP) relative to the $\mathrm{O}_{2} / \mathrm{H}_{2} \mathrm{~S}$ interface for all observations. Curve $1=10$ October 1996 (CAR-12), $2=7$ April 1997 (CAR18), 3 = 8 May 1997 (CAR-19), 4 = 14 November 1997 (CAR-25), $5=10$ March 1998 (CAR-29), $6=7$ July 1998 (CAR-32), $7=7$ November 1998 (CAR-36) and $8=7$ May 1999 (CAR-42). Complete BNP profiles for CAR-12 and CAR-18 are unavailable

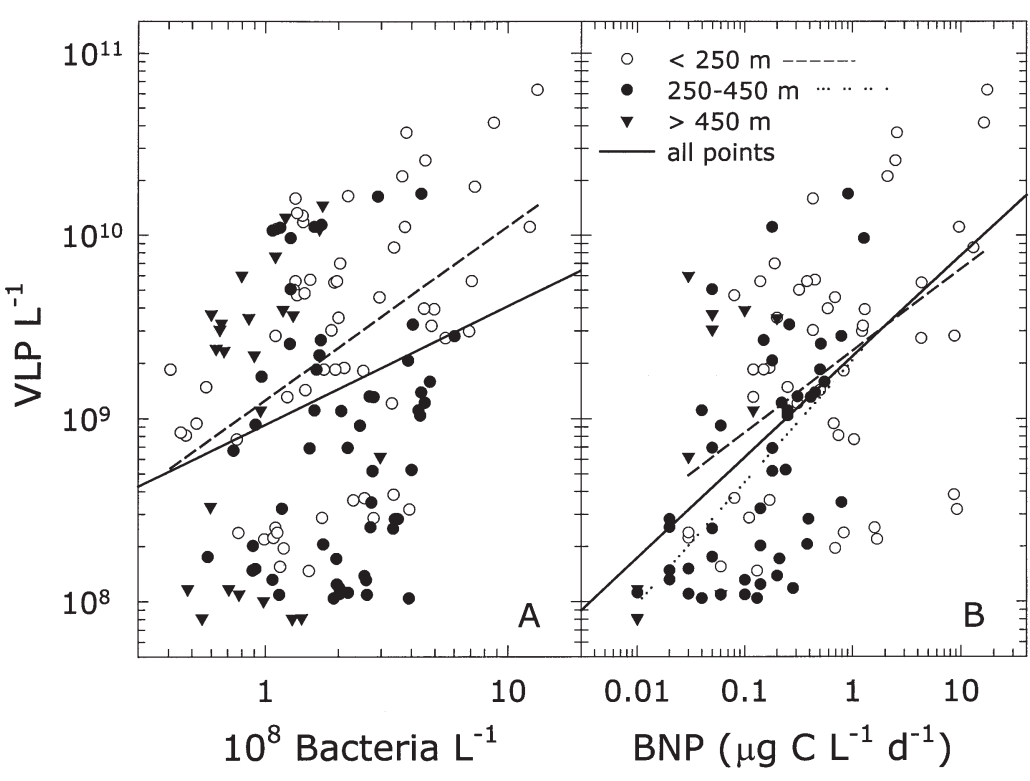

Fig. 5. Comparison of virus-like particle (VLP) concentrations to (A) bacterial concentrations and (B) bacterial net production (BNP) for all observations. Lines represent least-squares regressions for only those depth intervals within which variables were significantly correlated $(p<0.05)$

$\mathrm{n}=159$; Fig. 5A). However, among the 3 redox layers the correlation is only significant in the oxic layer $(\mathrm{r}=0.63, \mathrm{p}<0.001$; Tables $1 \& 2)$. More of the overall variation in VLP was explained by bacterial production (Fig. 5B), particularly in surface waters $(\mathrm{r}=0.64$, $\mathrm{p}<0.001)$ and to a lesser extent $(\mathrm{r}=0.46, \mathrm{p}<0.001)$ in the RTZ (Tables 1 \& 2). Regression slopes for oxic, RTZ and all layers combined are not significantly different $(\mathrm{p}>0.05$, ANCOVA) from one another (Fig. 5B), suggesting similar viral responses to BNP. In the upper $250 \mathrm{~m}$, VLP abundance was also significantly correlated with chl a $(\mathrm{r}=0.72, \mathrm{p}<0.001$; Table 1). Similarly, bacterial numbers and BNP were highly correlated with chl a (Table 1). While VLP and bacteria appear to be significantly correlated with NPP $(\mathrm{p}<0.05)$ in surface waters (Table 1), results from sequential Bonferroni tests suggest that these correlations could have arisen by chance alone, i.e. a Type I error. Although interactions between NPP and abundances of VLP or bacteria are expected, our data lack sufficient statistical power to support such predictions. 
In the RTZ, heterotrophic BNP and total bacterial abundance significantly correlated with chemoautotrophic production (Table 2). In contrast, VLP abundance did not appear to covary with activity of these midwater primary producers. VLP and VBR did, however, correlate with BNP and $\mu$ (Table 2). Results from the sequential Bonferroni test indicate that the significance of the correlation between VBR and BNP is insufficient to exclude the possibility of random association of these 2 variates. Nonetheless, correlative results suggest that VLP abundances were more closely linked to heterotrophic processes than chemoautotrophic processes.

In the anoxic layer, VLP and VBR tended to be higher relative to bacterial abundance and BNP than observed in the 2 shallower layers. However, variations in VLP and VBR were not significantly correlated with any other measured variables (not presented). The absence of correlation between VLP and BNP may result from underestimation of bacterial production in the anoxic layer (discussed below).

To further examine whether relationships between viruses and hosts were similar in all 3 layers, frequency distributions of VBR were examined for each layer (Fig. 6). In the oxic layer, the frequency distribution of VBR was distributed relatively evenly, with some suggestion of a mode in the 20 to 40 bin. About $50 \%$ of the samples had ratios of 10 to 20 or less. Ratios above the 20 to 40 bin were relatively rare. For anoxic samples, the frequency spectrum appeared bimodal, with $25 \%$

Table 1. Pearson product-moment correlations, r, between virus-like particles (VLP), phytoplankton and bacterial variables in the surface layer (0 to $250 \mathrm{~m}$ ). Numbers of observations (n) in parentheses. Net primary production (NPP), bacterial net product (BNP). Statistical significance of individual correlations, ${ }^{*} \mathrm{p}<0.05,{ }^{* *} \mathrm{p}<0.01,{ }^{* * *} \mathrm{p}<0.001, \mathrm{p}>0.05=$ ns (not significant)

\begin{tabular}{|c|c|c|c|c|c|c|c|}
\hline & $\begin{array}{l}\text { VLP } \\
\left(1^{-1}\right)\end{array}$ & $\begin{array}{l}\text { Chlorophyll } a^{\mathrm{a}} \\
\quad\left(\mu \mathrm{g} \mathrm{l}^{-1}\right)\end{array}$ & $\begin{array}{c}\mathrm{NPP}^{\mathrm{b}} \\
\left(\mu \mathrm{g} \mathrm{l^{-1 }} \mathrm{d}^{-1}\right)\end{array}$ & $\begin{array}{c}\text { Bacteria } \\
\quad\left(l^{-1}\right)\end{array}$ & $\begin{array}{c}\text { BNP } \\
\left(\mu \mathrm{g} \mathrm{l}^{-1} \mathrm{~d}^{-1}\right)\end{array}$ & $\begin{array}{l}\text { Heterotrophic } \\
\text { growth constant } \\
\qquad\left(\mathrm{d}^{-1}\right)\end{array}$ & $\begin{array}{l}\text { VLP:bacteria ratio } \\
\text { (dimensionless) }\end{array}$ \\
\hline VLP & $\mathrm{X}$ & $\begin{array}{l}0.72^{* * *} \\
(28)\end{array}$ & $\begin{array}{c}0.40^{*} \\
(28)\end{array}$ & $\begin{array}{l}0.63^{* * *} \\
(60)\end{array}$ & $\begin{array}{l}0.64^{* * *} \\
(51)\end{array}$ & $\begin{array}{c}\mathrm{ns} \\
(51)\end{array}$ & $\begin{array}{l}0.57^{* * *} \\
(60)\end{array}$ \\
\hline Chlorophyll $a$ & & X & $\begin{array}{l}0.61^{* * *} \\
(28)\end{array}$ & $\begin{array}{l}0.66^{* * *} \\
(28)\end{array}$ & $\begin{array}{l}0.89^{* * *} \\
(28)\end{array}$ & $\begin{array}{c}\text { ns } \\
(26)\end{array}$ & $\begin{array}{c}\text { ns } \\
(28)\end{array}$ \\
\hline NPP & & & $\mathrm{X}$ & $\begin{array}{c}0.45^{*} \\
(28)\end{array}$ & $\begin{array}{c}0.70^{* * *} \\
(28)\end{array}$ & $\begin{array}{l}\text { ns } \\
(26)\end{array}$ & $\begin{array}{c}\text { ns } \\
(28)\end{array}$ \\
\hline Bacteria & & & & $\mathrm{X}$ & $\begin{array}{c}0.67^{* * *} \\
(51)\end{array}$ & $\begin{array}{c}\text { ns } \\
(51)\end{array}$ & $\begin{array}{c}\text { ns } \\
(60)\end{array}$ \\
\hline BNP & & & & & $\mathrm{X}$ & $\begin{array}{l}0.45^{* * *} \\
(51)\end{array}$ & $\begin{array}{c}\text { ns } \\
(51)\end{array}$ \\
\hline $\begin{array}{l}\text { Heterotrophic } \\
\text { growth constant }\end{array}$ & & & & & & X & $\begin{array}{c}\text { ns } \\
(51)\end{array}$ \\
\hline
\end{tabular}

Table 2. Pearson product-moment correlations, r, between virus-like particles (VLP) and bacterial variables in the redox transition zone ( 250 to $450 \mathrm{~m})$. Format is the same as in Table 1

\begin{tabular}{|c|c|c|c|c|c|c|}
\hline & $\begin{array}{l}\text { VLP } \\
\left(1^{-1}\right)\end{array}$ & $\begin{array}{l}\text { Chemoautotrophic } \\
\text { production } \\
\left(\mu \mathrm{C} \mathrm{C}^{-1} \mathrm{~d}^{-1}\right)\end{array}$ & $\begin{array}{l}\text { Bacteria } \\
\quad\left(1^{-1}\right)\end{array}$ & $\begin{array}{c}\text { BNP } \\
\left(\mu \mathrm{C}^{-1} \mathrm{~d}^{-1}\right)\end{array}$ & $\begin{array}{l}\text { Heterotrophic } \\
\text { growth constant } \\
\qquad\left(\mathrm{d}^{-1}\right)\end{array}$ & $\begin{array}{l}\text { VLP:bacteria ratio } \\
\text { (dimensionless) }\end{array}$ \\
\hline VLP & $\mathrm{X}$ & $\begin{array}{l}\mathrm{ns} \\
(48)\end{array}$ & $\begin{array}{c}\mathrm{ns} \\
(55)\end{array}$ & $\begin{array}{l}0.46^{* * *} \\
(49)\end{array}$ & $\begin{array}{c}0.39^{* *} \\
(49)\end{array}$ & $\begin{array}{l}0.86^{* * *} \\
(55)\end{array}$ \\
\hline $\begin{array}{l}\text { Chemoautotrophic } \\
\text { production }\end{array}$ & & $\mathrm{X}$ & $\begin{array}{c}0.40^{* *} \\
(48)\end{array}$ & $\begin{array}{l}0.51^{* * *} \\
(48)\end{array}$ & $\begin{array}{c}0.37^{* *} \\
(47)\end{array}$ & $\begin{array}{c}\mathrm{ns} \\
(48)\end{array}$ \\
\hline Bacteria & & & X & $\begin{array}{r}0.34^{*} \\
(49)\end{array}$ & $\begin{array}{c}\text { ns } \\
(49)\end{array}$ & $\begin{array}{c}\mathrm{ns} \\
(55)\end{array}$ \\
\hline BNP & & & & X & $\begin{array}{l}0.82^{* * *} \\
(48)\end{array}$ & $\begin{array}{r}0.29^{*} \\
(49)\end{array}$ \\
\hline $\begin{array}{l}\text { Heterotrophic growth } \\
\text { constant }\end{array}$ & & & & & X & $\begin{array}{l}0.43^{* * *} \\
(49)\end{array}$ \\
\hline a Taylor et al. (2001) & & & & & & \\
\hline
\end{tabular}


of the samples containing ratios of $<2$ and $21 \%$ exhibiting ratios of 20 to 40 . In this layer, the frequency spectrum was skewed towards high ratios; $60 \%$ of samples had ratios above 20, and 25\% were above 60 . In contrast, the spectrum for RTZ samples was significantly skewed toward low ratios ( $\mathrm{p}<0.005$, Kolmogorov-Smirnov normality test); $65 \%$ of the samples exhibited ratios of 5 or less and samples with ratios above 20 were rare $(<20 \%$ of all samples).

A non-parametric test (Kruskal-Wallis rank ANOVA) was applied to VBR because the raw data violated assumptions of analysis of covariance (normal distribution, homogeneity of slopes and 'independent' variables free of measurement error). If interactions between VLP, bacteria and the environment were uniform, then observed ratios should be similarly distributed around comparable median values for each layer. In fact, median VBRs for oxic, transition and anoxic layers were significantly different $(p<0.0002) ; 16,3$ and 31, respectively (Fig. 6). In pairwise comparisons, rank sum distributions in the RTZ were significantly different from those of oxic and anoxic layers $(p<0.01$, Dunn's method). However, rank sum distributions in the oxic layer were not statistically distinct from those of the anoxic layer ( $p>0.05)$.

\section{Vertical transport of VLP and bacteria between layers}

Virioplankton can passively associate with seston by physical adsorption as free particles or within hosts or become packaged within feces of phagotrophs. Bacteria also adsorb to particles as well as actively colonizing and growing within them. Subsequent sedimentation of this debris is a possible transport mechanism influencing distributions. A significant range in fluxes of VLP was observed between dates, varying from 0.39 to $520 \times 10^{9}$ VLP $\mathrm{m}^{-2} \mathrm{~d}^{-1}$ (Fig. 7A). A similar range in vertical transport of bacteria was observed from 0.88 to $330 \times 10^{9}$ bacteria $\mathrm{m}^{-2} \mathrm{~d}^{-1}$ (Fig. 7B). Unlike suspended pools, bacterial abundance in sediment trap material was usually higher and more depth-dependent than that of VLP. For all sediment trap samples $(n=20)$, the mean VBR was 0.60 and the range was 0.01 to 1.2 . While fluxes of VLP and bacteria were strongly correlated with one another $(\mathrm{r}=0.74, \mathrm{p}<0.001)$, neither varied systematically with surface productivity. Primary production was highest in March 1998 (3.2 $\left.\mathrm{g} \mathrm{C} \mathrm{m}^{-2} \mathrm{~d}^{-1}\right)$, similar in all 3 Novembers $(0.60$ to $\left.0.76 \mathrm{~g} \mathrm{C} \mathrm{m}^{-2} \mathrm{~d}^{-1}\right)$ and lowest in July $1998\left(0.44 \mathrm{~g} \mathrm{C} \mathrm{m}^{-2}\right.$ $\mathrm{d}^{-1}$ ) (Fig. 7). No such temporal pattern is evident in the magnitude of vertical fluxes of VLP or bacteria (Fig. 7).

\section{DISCUSSION}

\section{Vertical and temporal variability in VLP distributions}

This is the first report of temporal variability in VLP distributions in a permanently stratified, anoxic marine basin. Suspended pools of VLP are a significant component of the planktonic community in the Cariaco Basin, varying from 0.08 to $63 \times 10^{9} \mathrm{VLPl}^{-1}$. This range is quite similar to oxic coastal and oceanic settings. For example, Cochlan et al. (1993) reported a range in VLP concentrations of 0.3 to $52 \times 10^{9} \mathrm{l}^{-1}$ for vertical profiles obtained from the Southern California Bight and the Gulf of Bothnia. Integrated over the entire Cariaco water column, VLP standing stocks varied between 0.2 and $16 \times 10^{15}$ VLP m${ }^{-2}$, and contributed on the order of 0.04 to $3.2 \mathrm{gC}$ $\mathrm{m}^{-2}$ to biotic carbon pools. While this only represents between 0.6 and $19 \%$ of the carbon biomass contributed by bacteria, their role in recycling prokaryotic and eukaryotic biomass through cell lysis may be much more profound (Bratbak et al. 1992, Fuhrman \& Noble 1995).

Our results clearly show that VLP distributions are influenced by plankton processes, similar to previous studies. For example, VLP varied concordantly with bacterioplankton, chl a, cyanobacteria and DNA pools along an offshore transect in the Gulf of Mexico and all variables decreased with depth (Boehme et al. 1993). Comparable correlations between VLP, bacteria and chl a have been reported for freshwater systems as well, such as Lac Gilbert and Lake Plußsee (Maranger

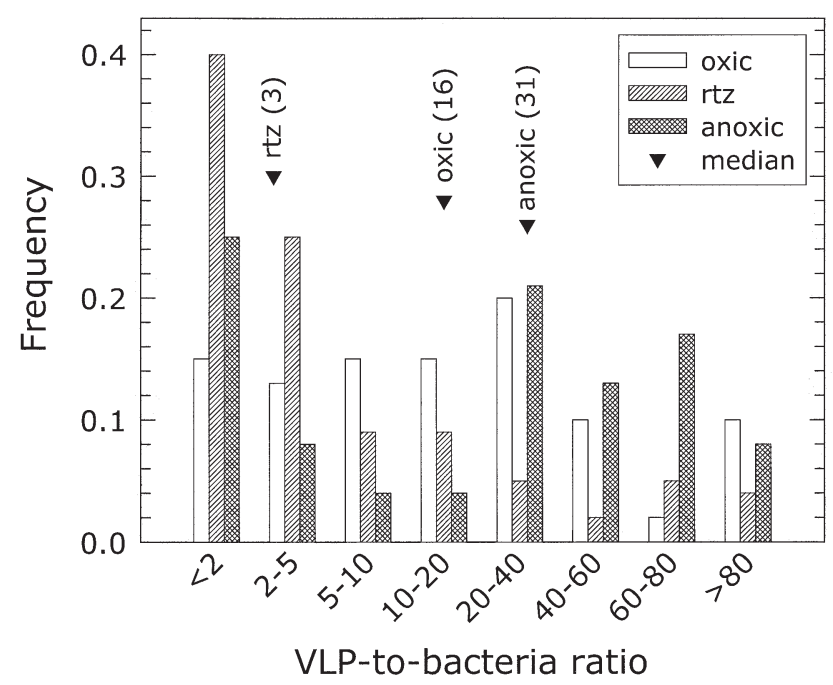

Fig. 6. Frequency spectra of suspended virus-like particles (VLP):bacteria ratios (VBR) for all samples in the oxic $(n=60)$, transition or redox transition zone (RTZ) $(n=55)$ and anoxic $(\mathrm{n}=24)$ layers. Arrows and numbers in parentheses denote median values for each layer 


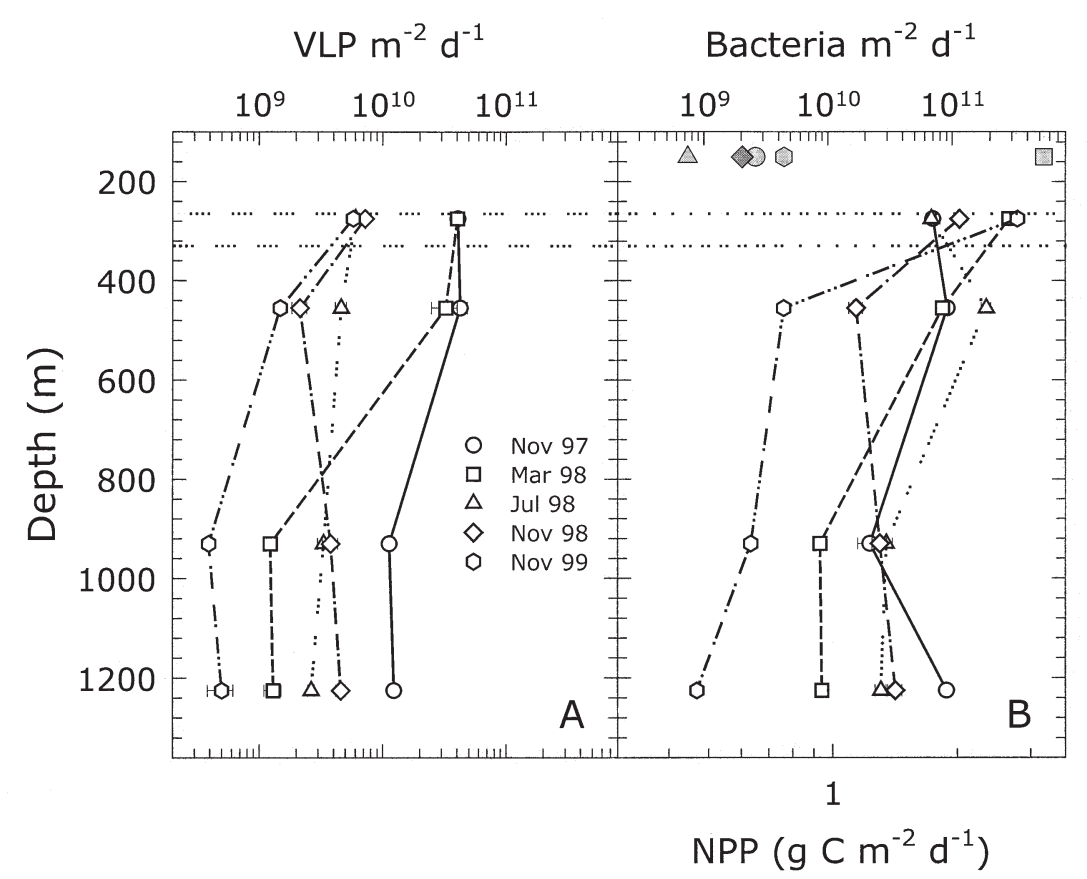

Fig. 7. Vertical fluxes of (A) virus-like particles (VLP) and (B) bacteria from the oxic layer, through the transition and anoxic layers over 5 collection intervals. Net primary production (NPP) integrated over the upper $100 \mathrm{~m}$ presented in (B) as shaded symbols (source, Taylor et al. 2001). Horizontal dotted lines represent the observed limits of the $\mathrm{O}_{2} / \mathrm{H}_{2} \mathrm{~S}$ interface excursion. Symbols and error bars represent the means and SE of the measurements. Width of SE is frequently smaller than that of symbols. Collection dates: 13 to 20 November 1997, 26 February to 12 March 1998, 1 to 15 July 1998, 7 to 21 November 1998 and 21 October to 2 November 1999

\& Bird 1996, Weinbauer \& Höfle 1998a). Vertical profiles of VLP, bacteria and BNP in the Cariaco Basin bear a close resemblance to those reported for Lake Plußsee, a highly stratified system with an anoxic hypolimnion (Weinbauer \& Höfle 1998a). Both systems exhibit maxima in the transition zone between oxic and anoxic conditions. Unlike the Cariaco Basin, the transition zone in Lake Plußsee is photosynthetically active and supports high chl a concentrations. Furthermore, the hypolimnion of Lake Plußsee is not sulfidic as is the anoxic layer of the Cariaco Basin.

In the Cariaco Basin, the position of the $\mathrm{O}_{2} / \mathrm{H}_{2} \mathrm{~S}$ interface is usually more than $200 \mathrm{~m}$ below the base of the photic zone. The depth of the midwater VLP maximum seemed to be controlled by the position of this interface to a greater extent than was bacterial abundance (Fig. 4). VLP distributions in the RTZ appear to respond, in part, to peaks in BNP, which are found within $10 \mathrm{~m}$ above and $30 \mathrm{~m}$ below the $\mathrm{O}_{2} / \mathrm{H}_{2} \mathrm{~S}$ interface (Fig. 4). Maxima in heterotrophic bacterial production generally overlap with peaks in chemoautotrophic production (Taylor et al. 2001). Organic matter production by chemoautotrophy immediately below the $\mathrm{O}_{2} / \mathrm{H}_{2} \mathrm{~S}$ interface can rival that of photoautotrophy in the photic zone and is well in excess of sedimenting biogenic debris entering this layer (Taylor et al. 2001). This midwater source of organic carbon production presumably supports, in large part, an anaerobic microbial loop of heterotrophic bacteria, protozoan grazers and viral parasites. Interestingly, VLP did not correlate directly with chemoautotrophic activity, even though bacteria and BNP did.

Despite evidence for active bacterial growth, which should in turn stimulate viral production, the RTZ tends to have lower VBR than the other 2 layers. This unexpected condition could arise if: (1) grazing pressure on bacteria were low relative to production; (2) viral burst sizes were lower; or (3) viral removal rates were high compared to the other 2 layers. Concentrations of both flagellated and ciliated protozoa are consistently high in the RTZ and diminish at depths immediately above and below (M. Iabichella \& G. T. Taylor unpubl. data). Therefore, grazing pressure in this layer is likely to be high, especially compared to the anoxic layer. We are left with the hypothesis that viral production is lower or that viral removal processes are more active in this zone than in neighboring waters.

The present investigation is one of few marine studies to examine temporal changes in VLP and other plankton variables at a single site. As in 2 previous short-term time series studies (Bratbak et al. 1990, Jiang \& Paul 1994), we observed much greater variability in abundance of VLP than of bacteria. Over our observation period, integrated standing stocks of VLP varied almost 100 -fold, while those of bacteria by only about 3 -fold. The low temporal variance in bacterial abundance suggests relatively tight controls on bacterial production, presumably exerted by bacteriophages and protozoan grazers. The greater variance in VLP may reflect the range in productivity of the dominant viral hosts because production of free viruses is intimately linked to both growth rates and population densities of hosts.

To which host organisms are viruses responding in the Cariaco Basin? In other marine systems, correlative analyses suggest that the majority of viruses are bacteriophages and the remainder are mostly phytophages (Suttle 1994). In the Cariaco's surface waters, bacterial abundance can account for as much as $63 \%$ of the variance in VLP, similar to other coastal and oceanic settings, e.g. $67 \%$ reported by Cochlan et al. (1993). Cor- 
relations between VLP and phytoplankton reported here and elsewhere may largely result from an indirect relationship because bacterial variables also covary strongly with phytoplankton. Consequently, bacteriophage levels could give the appearance of responding to variations in primary production because of a secondary trophic connection. Previous morphologic surveys and molecular analysis of viral assemblages conclude that the majority of marine virioplankton appear to be typical bacteriophages (Proctor \& Fuhrman 1990, Cochlan et al. 1993, Fuhrman \& Suttle 1993, Oren et al. 1997, Steward et al. 2000). While speculative, all available information leads us to surmise that viral communities in the Cariaco system are also dominated by bacteriophages.

Nonetheless, the quantitative relationship between suspended VLP and bacteria, VBR, varied about 400 -fold from 0.3 to 120 and averaged 22. Our mean value is similar to that obtained through regression analysis $(\sim 12)$ by Cochlan et al. (1993) for coastal waters and reported for Chesapeake Bay waters (12 to 17) by Drake et al. (1998). In comparative studies of freshwater and marine planktonic systems, VBR have been reported to vary from 0.03 to 80 , suggesting that viruses are a highly dynamic component of aquatic food webs in general (Maranger \& Bird 1995, Wommack \& Colwell 2000). Production of bacteria was far more variable than their abundance, integrated BNP varying by a factor of 8 , but still not nearly as variable as VLP stocks. Clearly, processes other than host abundance and production are important in controlling temporal oscillations in suspended VLP concentrations.

\section{Viruses and anoxia}

Maranger \& Bird (1996) observed that VBR were significantly lower in anoxic regions than in oxic regions of a lake's surficial sediments (top $1 \mathrm{~cm}$ ). Together with thermodynamic considerations of anaerobes' metabolic inefficiencies, this might imply that the Cariaco's anoxic layer would support proportionately smaller viral pools than overlying waters. Our observations, however, do not support such a hypothesis. Suspended VLP pools and VBR in the Cariaco Basin do not appear to be diminished by anoxic conditions. In fact, the median VBR for all observations in the anoxic layer is higher than in overlying layers. The relatively high frequency of large ratios in the less productive, anoxic samples and the low VBRs in the productive RTZ are somewhat paradoxical.

High VBRs observed at depths of low BNP and $\mu$ (below $450 \mathrm{~m}$ ) may arise for several reasons. In anoxic waters, VBR may appear high relative to BNP because the ${ }^{3} \mathrm{H}$-leucine technique underestimates production of anaerobic heterotrophs (a technical artifact). It is known that some sulfate-reducing bacteria are incapable of utilizing exogenous ${ }^{3} \mathrm{H}$-thymidine (Gilmour et al. 1990) and a bias against ${ }^{3} \mathrm{H}$-leucine is also possible. Analyses of bacterial production in the Cariaco Basin by independent methods do indeed suggest that BNP measured by the ${ }^{3} \mathrm{H}$-leucine technique is underestimated in sulfidic waters (M. Iabichella unpubl. data). This apparently is not the case in anoxic freshwaters where ${ }^{3} \mathrm{H}$-leucine incorporation rates in anoxic hypolimnia can exceed contemporaneous rates in oxic epilimnia (Cole \& Pace 1995). Further research is required to resolve this issue.

VBRs would also be high relative to measurements of production if viruses were released during an earlier period of high productivity and then remained in suspension (a temporal artifact). However, the improbability of encountering this situation on all 8 cruises argues against this explanation. Another possibility is that burst sizes and rates of infection of anaerobic bacteriophages (progeny per infection) are larger than those of aerobes. We have no direct estimates of burst size or infection rates in our samples. Weinbauer \& Höfle (1998b) observed that the frequency of bacteria visibly infected with viruses increased from the oxic epilimnion $(1.2 \%)$, through the metalimnion $(2.4 \%)$ to the anoxic hypolimnion $(4.5 \%)$ of Lake Plußsee. They also noted a positive correlation between bacterial cell volume and burst size of bacteriophages, which both increased with depth. Similar to several freshwater systems examined by Cole et al. (1993) and Weinbauer \& Höfle (1998b), median cell volumes of bacteria in the Cariaco's anoxic layer appear to be significantly greater than those in the oxic layer or RTZ (M. Iabichella unpubl. data), which is largely explained by the prevalence of filamentous forms at depth. Larger burst sizes are a predictable outcome from larger host cells residing in the Cariaco's anoxic layer. Consequently, even if anaerobic bacterial production were slower than that of aerobes, release of virioplankton may be comparable due to higher infection frequencies and/or possibly larger burst sizes.

\section{VLP residence times}

Abundances of virioplankton reflect the balance between their rates of production through host lysis and rates of removal by any of several mechanisms. Viral communities may turn over as rapidly as every 1 to $2 \mathrm{~d}$, even in oligotrophic waters, which equates to removal rates of 0.43 to $1.5 \mathrm{~d}^{-1}$ (Noble \& Fuhrman 2000). Processes postulated to remove virioplankton from sus- 
pension include infection of new hosts, particle scavenging and sinking with debris, chemical decay and ingestion by suspension feeders (mostly phagotrophic protozoa). We have no information on the dynamics of viral transmission and infection in the Cariaco Basin, although these processes have been examined elsewhere (e.g. Murray \& Jackson 1992, Proctor et al. 1993, Bratbak et al. 1994, Weinbauer \& Höfle 1998a,b, Thingstad 2000). Subsequent discussion will focus on the importance of the remaining removal processes to virioplankton communities and how they may differ between layers in the Cariaco Basin.

Adsorption to detritus has been advanced as a major factor in loss of viral infectivity, transport from zones of active particle production to those of particle disintegration and export from the water column to the seabed (Suttle \& Chen 1992, Noble \& Fuhrman 1997). Viruses have been observed in sinking biogenic debris collected in sediment traps, primarily as visible infections of particle-associated bacteria and eukaryotes (Proctor \& Fuhrman 1991). From these observations, one might postulate that high abundances of suspended VLP at depth could result from transport of debris, derived from surface waters, which is solubilized during sinking. Concentrates of marine virioplankton have been shown experimentally to stimulate production of marine snow through algal lysis (Peduzzi \& Weinbauer 1993). Presumably, viruses would be an integral component of any marine snow formed by this process and both would contribute to the vertical car- bon flux. In fact, Bird et al. (1993) estimated daily losses from surface waters of about $4 \%$ for VLP associated with sinking particles in the Southern Ocean, based on a single day's collection of a sediment trap at $60 \mathrm{~m}$. In the Cariaco Basin, fluxes of VLP, like bacteria and particulate carbon, varied widely between observations and frequently decreased with depth (Thunell et al. 2000, Muller-Karger et al. 2001, Taylor et al. 2001, this study). Surprisingly, concentrations of VLP in sediment trap material, and therefore vertical fluxes, were almost always lower than those of bacteria, resulting in VBRs typically $<1.0$.

To evaluate the importance of sedimentation of microbe-laden particles in transporting VLP and bacteria between layers, a simple 4-layered box model was constructed from sediment trap and water column data. Comparing the integrated pool size of suspended VLP $\mathrm{m}^{-2}$ within a layer to the flux of VLP out of that layer (VLP $\mathrm{m}^{-2} \mathrm{~d}^{-1}$ ) suggests that removal of viruses by sedimenting particles is exceedingly slow in all layers, varying from 0.003 to $0.57 \% \mathrm{mo}^{-1}$ and averaging $0.11 \% \mathrm{mo}^{-1}$ (Table 3 ). The mean removal rate for bacteria was 40 times faster than for VLP, but rates $(0.50$ to $12 \% \mathrm{mo}^{-1}$ ) were still surprisingly slow compared to expected bacterial production rates $\left(\sim 3\right.$ to $\left.100 \% \mathrm{~d}^{-1}\right)$. Time and depth-dependent trends in removal rates were not apparent from either VLP or bacterial data. Vertical transport of viruses is probably controlled by complex interactions among physical (turbulence and thermohaline structure), chemical (particle composi-

Table 3. Comparison of virus-like particles (VLP) and bacteria suspended in the water column with sinking fluxes of particleassociated organisms during upwelling and relaxed conditions. Suspended pools are values integrated from discrete depths over 4 intervals defined by placement of sediment traps. Sinking fluxes are derived from sediment traps deployed at lower boundary of depth interval. Removal rates are 0-order rate constants (sinking flux/suspended pools), illustrating loss rates if particle scavenging of suspended biota and sedimentation were the only removal mechanism. Grand mean includes data for 13 to 20 November 1997, 26 February to 12 March 1998, 1 to 15 July 1998 and 7 to 21 November 1998

\begin{tabular}{|c|c|c|c|c|c|c|}
\hline \multirow{2}{*}{$\begin{array}{l}\text { Depth interval } \\
\text { (m) }\end{array}$} & \multicolumn{3}{|c|}{ Mar 98} & \multicolumn{3}{|c|}{ - Nov 98} \\
\hline & $\begin{array}{l}\text { Suspended } \\
\left(\times 10^{14} \mathrm{~m}^{-2}\right)\end{array}$ & $\begin{array}{c}\text { Sinking flux } \\
\left(\times 10^{9} \mathrm{~m}^{-2} \mathrm{~d}^{-1}\right)\end{array}$ & $\begin{array}{l}\text { Removal } \\
\left(\% \mathrm{mo}^{-1}\right)\end{array}$ & $\begin{array}{l}\text { Suspended } \\
\left(\times 10^{14} \mathrm{~m}^{-2}\right)\end{array}$ & $\begin{array}{c}\text { Sinking flux } \\
\left(\times 10^{9} \mathrm{~m}^{-2} \mathrm{~d}^{-1}\right)\end{array}$ & $\begin{array}{l}\text { Removal } \\
\left(\% \mathrm{mo}^{-1}\right)\end{array}$ \\
\hline \multicolumn{7}{|l|}{ VLP } \\
\hline$<275$ & 24 & 41 & 0.05 & 4.3 & 7.2 & 0.05 \\
\hline 275 to 455 & 2.9 & 33 & 0.33 & 0.30 & 2.1 & 0.21 \\
\hline 455 to 930 & 13 & 1.2 & 0.003 & 0.39 & 3.8 & 0.29 \\
\hline 930 to 1255 & 5.6 & 1.3 & 0.007 & 0.24 & 4.6 & 0.57 \\
\hline Mean & & & $0.1 \ddot{\mathrm{I}} 0$ & & & 0.28 \\
\hline Grand mean $(\mathrm{n}=16)$ & & & & & & 0.11 \\
\hline \multicolumn{7}{|l|}{ Bacteria } \\
\hline$<275$ & 0.71 & 280 & 12 & 0.77 & 114 & 4.5 \\
\hline 275 to 455 & 0.41 & 83 & 6.1 & 0.41 & 17 & 1.2 \\
\hline 455 to 930 & 0.51 & 8.6 & 0.51 & 0.64 & 26 & 1.2 \\
\hline 930 to 1255 & 0.32 & 9.0 & 0.84 & 0.41 & 35 & 2.6 \\
\hline Mean & & & 4.9 & & & 2.4 \\
\hline Grand mean $(\mathrm{n}=16)$ & & & & & & 4.6 \\
\hline
\end{tabular}


tion) and biological (productivity, community structure and growth of hosts on particles) variables. We could not discern any consistent differences between oxic, transition and anoxic layers in VLP removal rates by sedimentation.

It is true that our estimates of sinking fluxes of VLP and bacteria are conservative because of the methods employed. While most VLP and bacteria enumerated microscopically were dispersed into suspension before filtering by sonication, $\leq 25 \%$ of the apparent VLP were still associated with small particles $(<50 \mu \mathrm{m})$ in the preparations. Particle density on the filters was minimized by diluting samples by as much as a 1000 -fold. Organisms on the upper surfaces of particles were included in the census, but those on the lower surface or interior of particles were not. Viruses contained in host cells were also ignored by our techniques. The literature suggests that the frequency of visibly infected cells among suspended and sinking bacteria are similar; 0.7 to $9.0 \%$ of marine and lacustrine bacterioplankton and 0.7 to $3.7 \%$ for seston-associated bacteria (Proctor \& Fuhrman 1991, Proctor et al. 1993, Fuhrman \& Noble 1995, Weinbauer \& Höfle 1998a). If frequencies of infection are, in fact, comparable among suspended and sedimenting bacteria, then estimates of viral removal in the Cariaco Basin are little affected by ignoring viruses transported within hosts.

Of necessity, all samples for microscopic enumeration were preserved and stored for varying time intervals before staining, filtration and enumeration. Apparent bacterial numbers in preserved samples are known to decline as a first-order function of the time elapsed between preservation and slide preparation, and this decay rate varies with preservation and storage conditions, e.g. temperature and fixative (Turley \& Hughes 1994). Our own preliminary experiments suggest that under our preservation, storage $\left(4\right.$ to $\left.8^{\circ} \mathrm{C}\right)$ and handling conditions, apparent VLP decay at a rate, $k_{\text {, }}$ of about $0.005 \mathrm{~d}^{-1}$. Correction for loss of detectable VLP can be approximated using $N_{0}=N / \mathrm{e}^{-k t}$, where $N_{0}$ and $N$ are concentrations of detectable VLP at the time of preservation and analysis, respectively, and $t$ is the time elapsed between these procedures. Application of this correction suggests that our storage conditions may have produced 1.1- to 3.4-fold underestimates for suspended VLP pools and at least 108- to 672 -fold for the VLP fluxes presented in Table 3 . We note that sediment trap materials were preserved in situ, immediately upon sinking into the collection cup, but may have remained at ambient temperatures $\left(17\right.$ to $\left.18^{\circ} \mathrm{C}\right)$ for several months before retrieval and refrigeration. Decay rates during this period are unknown, but were undoubtedly higher than the $k$ applied to the entire storage interval. This uncertainty aside, loss-corrected model calculations increase removal rates of VLP to between 0.6 and $69 \% \mathrm{mo}^{-1}$ and average $11 \% \mathrm{mo}^{-1}$. Clearly, viruses are transported with sedimenting debris. However, the low vertical fluxes suggest that sedimentation from more productive surface waters can only remove a very small portion of the suspended VLP inventories and supplies little to underlying waters. These results also suggest that most suspended VLP observed in anoxic waters in all likelihood were produced in situ through infection and lysis of anaerobic hosts. Loss mechanisms other than sedimentation must be invoked to balance continuous production of free viruses because viral pool sizes are not systematically growing.

Other processes removing VLP from suspension, such as viral decay and consumption by suspension feeders, are poorly understood in oxic surface waters and virtually unstudied in anoxic systems. In surface waters, reported decay rates of viruses vary from 0.12 to $26 \mathrm{~d}^{-1}$, estimated from loss of infectivity in shortterm experiments (Heldal \& Bratbak 1991, Suttle \& Chen 1992, Noble \& Fuhrman 1997). These authors conclude that photochemical decay, sorption to particles, interactions with ectoenzyme-like colloidal materials and ingestion by small suspension feeders are all processes removing infective viruses. The photic zone in the Cariaco Basin is seldom deeper than $60 \mathrm{~m}$; therefore, photochemically induced decay is not expected to significantly affect viral dynamics throughout most of this $1400 \mathrm{~m}$ water column.

Decay rates of viruses have been experimentally stimulated by the presence of flagellated protozoa, small suspension feeders, but these organisms could only consume an estimated $2.4 \%$ of the viral community daily (Suttle \& Chen 1992). Subsequently, Gonzales \& Suttle (1993) demonstrated that natural flagellate assemblages cleared fluorescently labeled viruses $96 \%$ less efficiently than they clear bacteria. Using Gonzales \& Suttle's (1993) range of viral clearance rates for flagellates (0.03 to $0.19 \mathrm{nl} \mathrm{cell}^{-1} \mathrm{~h}^{-1}$ ) and our maximum observed flagellate concentrations (1600 cells ml ${ }^{-1}, \mathrm{M}$. Iabichella unpubl. data), we estimate that these phagotrophs can only clear suspended VLP at rates of 0.001 to $0.007 \mathrm{~d}^{-1}$. Therefore, removal of free VLP by grazing appears to be trivial compared to expected production rates. Even though virioplankton are typically 2 to 10 times more abundant than bacterioplankton, their small size may provide refuge from grazing unless concentrated on larger microaggregates.

Contrary to predictions based on differences in metabolic efficiencies of aerobic and anaerobic bacteria, our results demonstrate that VLP in the anoxic waters of the Cariaco Basin are as numerically important as they are in oxic waters. Relative abundances of VLP do vary temporally and between redox layers, 
with the RTZ systematically exhibiting the lowest VBRs. Factors controlling viral dynamics are still poorly understood. Production of free VLP in all layers probably varies as a function of the hosts' growth rate and phylogenetic diversity, and viral infection rates and burst sizes. However, removal processes are less straightforward. Vertical transport by association with sinking debris and grazing by flagellates appear to be of minor importance in explaining viral removal, accounting for maximum turnover rates of no more than $71 \% \mathrm{mo}^{-1}$ and averaging about $13 \%$. Further studies of production, decay and scavenging processes below the photic zone and across the redox boundary as well as biological clearance of viruses associated with microaggregates are warranted.

Acknowledgements. The authors are grateful to the captain and crew of the BO 'Hermano Gines' and the staff of the Estación de Investigaciones Marinas de Margarita (Fundación la Salle de Ciencias Naturales, Punta de Piedras, Isla de Margarita, Venezuela) for their field assistance in this study. Our gratitude to F. Muller-Karger for his tireless efforts to make Project CARIACO a success. We are indebted to R. Varela, Y. Astor, R. Thunell, A. Modanesi and X. Lin for phytoplankton data, $\mathrm{O}_{2}$ data, sediment trap samples and laboratory assistance, respectively. We are also grateful to $\mathrm{M}$. I. Scranton and J. Sprague for their helpful comments on this manuscript. This research was supported by US National Science Foundation grants OCE9415790, OCE9711318 and OCE9730278. This is Marine Sciences Research Center contribution no. 1255.

\section{LITERATURE CITED}

Bird DF, Maranger R, Karl DM (1993) Palmer LTER: aquatic virus abundances near the Antarctic Peninsula. Antarct $\mathrm{J}$ Rev 28:234-235

Boehme J, Frischer ME, Jiang SC, Kellogg CA, Pichard S, Rose JB, Steinway C, Paul JH (1993) Viruses, bacterioplankton, and phytoplankton in the southeastern Gulf of Mexico: distribution and contribution to oceanic DNA pools. Mar Ecol Prog Ser 97:1-10

Bratbak G, Heldal M, Norland S, Thingstad TF (1990) Viruses as partners in spring bloom microbial trophodynamics. Appl Environ Microbiol 56:1400-1405

Bratbak G, Heldal M, Thingstad TF, Riemann B, Haslund OH (1992) Incorporation of viruses into the budget of microbial C-transfer. Mar Ecol Prog Ser 83:273-280

Bratbak G, Thingstad F, Heldal M (1994) Viruses and the microbial loop. Microb Ecol 28:209-221

Cochlan WP, Wikner J, Steward GF, Smith DC, Azam F (1993) Spatial distribution of viruses, bacteria and chlorophyll a in neritic, oceanic and estuarine environments. Mar Ecol Prog Ser 92:77-87

Cole JJ, Pace ML (1995) Bacterial secondary production in oxic and anoxic freshwaters. Limnol Oceanogr 40:1019-1027

Cole JJ, Pace ML, Steinhart G, Caraco NF (1993) Bacterial biomass and cell size distributions in lakes: more and larger cells in anoxic waters. Limnol Oceanogr 38:1627-1632

Drake L, Choi KH, Haskell AGE, Dobbs FC (1998) Vertical profiles of VLP and bacteria in the water column and sediments of the Chesapeake Bay, USA. Aquat Microb Ecol $16: 17-25$
Fenchel T, Finlay BJ (1994) The evolution of life without oxygen. Am Sci 82:22-29

Fuhrman JA, Noble RT (1995) Viruses and protists cause similar bacterial mortality in coastal seawater. Limnol Oceanogr 40:1236-1242

Fuhrman JA, Suttle CA (1993) Viruses in marine planktonic systems. Oceanography 6:51-63

Fukuda R, Ogawa H, Nagata T, Koike I (1998) Direct determination of carbon and nitrogen contents of natural bacterial assemblages in marine environments. Appl Environ Microbiol 64:3352-3358

Gilmour CC, Leavitt ME, Shiaris MP (1990) Evidence against incorporation of exogenous thymidine by sulfate-reducing bacteria. Limnol Oceanogr 35:1401-1409

Gonzales JM, Suttle CA (1993) Grazing by marine nanoflagellates on viruses and virus-sized particles: ingestion and digestion. Mar Ecol Prog Ser 94:1-10

Hara S, Koike I, Terauchi K, Kamiya H, Tanoue E (1996) Abundance of viruses in deep oceanic waters. Mar Ecol Prog Ser 145:269-277

Heldal M, Bratbak G (1991) Production and decay of viruses in aquatic environments. Mar Ecol Prog Ser 72:205-212

Jiang SC, Paul JH (1994) Seasonal and diel abundance of viruses and occurrence of lysogeny/bacteriocinogeny in the marine environment. Mar Ecol Prog Ser 104: $163-172$

Kirchman DL (1993) Leucine incorporation as a measure of biomass production by heterotrophic bacteria. In: Kemp PF, Sherr BF, Sherr EB, Cole JJ (eds) Handbook of methods in aquatic microbial ecology. Lewis Publishers, Boca Raton, FL, p 509-512

Kirchman DL, Sigida, J, Kapuscinski R, Mitchell R (1982) Statistical analysis of the direct count method for enumerating bacteria. Appl Environ Microbiol 44:376-382

Madrid VM, Taylor GT, Scranton MI, Chistoserdov AY (2001) Phylogenetic diversity of Bacterial and Archaeal communities in the anoxic zone of the Cariaco Basin. Appl Environ Microbiol 67:1663-1674

Maranger R, Bird DF (1995) Viral abundance in aquatic systems: a comparison between marine and fresh waters. Mar Ecol Prog Ser 121:217-226

Maranger R, Bird DF (1996) High concentrations of viruses in the sediments of Lac Gilbert. Microb Ecol 31:141-151

Muller-Karger FR, Varela R, Thunell R, Scranton M and 7 others (2001) Annual cycle of primary production in the Cariaco Basin: response to upwelling and implications for vertical export. J Geophys Res 106:4527-4542

Murray AG, Eldridge P (1994) Marine viral ecology: incorporation of bacteriophage into the microbial planktonic food web paradigm. J Plankton Res 16:627-641

Murray AG, Jackson GA (1992) Viral dynamics: a model of the effects of size, shape, motion and abundance of singlecelled planktonic organisms and other particles. Mar Ecol Prog Ser 89:103-116

Noble RT, Fuhrman JA (1997) Virus decay and its causes in coastal waters. Appl Environ Microbiol 63:77-83

Noble RT, Fuhrman JA (1998) Use of SYBR Green I for rapid epifluorescence counts of marine viruses and bacteria. Aquat Microb Ecol 14:113-118

Noble RT, Fuhrman JA (2000) Rapid virus production and removal as measured with fluorescently labeled viruses as tracers. Appl Environ Microbiol 66:3790-3797

Norland S (1993) The relationship between biomass and volume of bacteria. In: Kemp PF, Sherr BF, Sherr EB, Cole JJ (eds) Handbook of methods in aquatic microbial ecology. Lewis Publishers, Boca Raton, FL, p 303-308

Oren A, Bratbak G, Heldal M (1997) Occurrence of virus-like 
particles in the Dead Sea. Extremophiles 1:143-149

Peduzzi P, Weinbauer MG (1993) Effect of concentrating the virus-rich 2-200-nm size fraction of seawater on the formation of algal flocs (marine snow). Limnol Oceanogr 38: 1562-1565

Porter KG, Feig YS (1980) The use of DAPI for identifying and counting microflora. Limnol Oceanogr 25:943-948

Proctor LM, Fuhrman JA (1990) Viral mortality of marine bacteria and cyanobacteria. Nature 343:60-62

Proctor LM, Fuhrman JA (1991) Roles of viral infection in organic particle flux. Mar Ecol Prog Ser 69:133-142

Proctor LM, Okubo A, Fuhrman JA (1993) Calibrating estimates of phage-induced mortality in marine bacteria: ultrastructural studies of marine bacteriophage development from one-step growth experiments. Microb Ecol 25: 161-182

Rice WR (1989) Analyzing tables of statistical tests. Evolution 43:223-225

Steward GF, Montiel JL, Azam F (2000) Genome size distributions indicate variability and similarities among marine viral assemblages from diverse environments. Limnol Oceanogr 45:1697-1706

Suttle CA (1994) The significance of viruses to mortality in aquatic microbial communities. Microb Ecol 28:237-243

Suttle CA, Chen F (1992) Mechanisms and rates of decay of marine viruses in seawater. Appl Environ Microbiol 58: 3721-3729

Taylor GT, Scranton MI, Iabichella M, Ho TY, Thunell RC,

Editorial responsibility: Gunnar Bratbak,

Bergen, Norway
Muller-Karger F, Varela R (2001) Chemoautotrophy in the redox transition zone of the Cariaco Basin: a significant midwater source of organic carbon production. Limnol Oceanogr 46:148-163

Thingstad TF (2000) Elements of a theory for the mechanisms controlling abundance, diversity, and biogeochemical role of lytic bacterial viruses in aquatic systems. Limnol Oceanogr 45:1320-1328

Thunell RC, Varela R, Llano M, Collister J, Muller-Karger F, Bohrer R (2000) Organic carbon fluxes and regeneration rates in an anoxic water column: sediment trap results from the Cariaco Basin. Limnol Oceanogr 45:300-308

Turley CM, Hughes DJ (1994) The effect of storage temperature on the enumeration of epifluorescence-detectable bacterial cells in preserved sea-water samples. J Mar Biol Assoc UK 74:259-262

UNESCO (1994) Protocols for the Joint Global Ocean Flux Study (JGOFS) Core Measurements. IOC Manuals and Guides, 29. UNESCO, Paris, p 128-140

Weinbauer MG, Höfle MG (1998a) Significance of viral lysis and flagellate grazing as factors controlling bacterioplankton production in a eutrophic lake. Appl Environ Microbiol 64:431-438

Weinbauer MG, Höfle MG (1998b) Size-specific mortality of lake bacterioplankton by natural virus communities. Aquat Microb Ecol 15:103-113

Wommack KE, Colwell RR (2000) Virioplankton: viruses in aquatic ecosystems. Microbiol Mol Biol Rev 64:69-114

Submitted: July 25, 2001; Accepted: August 31, 2002

Proofs received from author(s): November 18, 2002 